\title{
Visioner er der nok af, men handlekraft?
}

\author{
Af Preben Melander *)
}

Vi taler meget om tidens store teknologiske, sociale og politiske udviklingsmuligheder, men er der tilstrækkelig samfundsmæssig opbakning og handlekraft, når det kommer til stykket?

Vi lever i en tid, hvor alt synes under opbrud, og hvor vi i medierne og i den politiske debat taler om fremtidens store udviklings- og samarbejdspotentialer. Men når vi ser på de faktiske forandringer og de reelle opnåede fremskridt, må vi nok konstatere, at der er langt mellem visionernes uendelige muligheder og de faktiske politiske handlingsresultater.

Lad os tage et kendt eksempel med desværre skuffende resultater: Det nordiske samarbejde. Da Øresundsbroen blev bygget, var der store politiske visioner om de fantastiske muligheder for økonomisk, politisk og institutionelt samarbejde mellem Sydsverige og Østdanmark. Man så Øresundsregionen som en ny og global økonomisk region, der ville tiltrække mennesker, viden, kapital, arbejdskraft og samspil til gavn for hele Skandinavien.

$\mathrm{Nu}$ står broen der. Og den har stået der nu i 25 år. Og mulighederne er stadig oplagte. Men der mangler de institutionelle strukturer, som skal til for at mobilisere og fastholde de tværgående samspilsprocesser. Der mangler politisk handlekraft på begge sider af Øresund. Pendlerne var fra starten på banen. De ville gerne være med til at prøve noget nyt. Mange mennesker var interesseret i at arbejde på den anden side af Sundet. Men interessen faldt stødt over de følgende 10 år.

Det skyldes ikke kun grænselukningerne som følge af Coronaen og flygtninge-presset. Allerede før Coronaen faldt interessen for at etablere nye samarbejdsmuligheder på tværs af Sundet. I starten oprettedes transportsamarbejdet i form af "Øresundstog" med nye og hyppige togforbindelser

*) Preben Melander er professor emeritus og ansvarshavende redaktør for Samfundslederskab i Skandinavien. 
mellem byerne i Skåne og på Sjælland. Tænk at man kunne tage toget fra København og direkte til Göteborg eller til Växjö. Men der var mange besværlige administrationsproblemer med at etablere en region på tværs. At udvikle en fælles skandinavisk enhed, der kunne fungere i praksis med fælles skatteregler, arbejdsmarkedsforhold, kommunalt samarbejde og med tværgående udviklingsinitiativer, fælles kulturprojekter etc. var åbenbart en for stor udfordring.

Den politiske interesse og handlekraft er simpelthen forsvundet, og i dag er Øresundsregionen en død sild. Transportmulighederne er under nedskæring. Der er end ikke politisk interesse i at undersøge, hvorfor Øresundsregionen blev en fiasko. Tilsvarende problemer gælder, når vi ser på det skandinaviske samarbejde på tværs indenfor forskerverdenen. Her var der for 20 år siden mange lokale initiativer til projektsamarbejde mellem universiteterne. Men de er blevet færre. Det giver jo ikke merit at skrive sammen på skandinavisk. Det giver mere at publicere en artikel i et specialiseret engelsk tidsskrift, som kun læses af ganske få eksperter. De globale meriteringer er åbenbart vigtigere end de nære lokale faglige udviklingsmuligheder. 